\title{
ANALYSIS OF THE IMPACT OF COVID ON THE UKRAINIAN TOURISM INDUSTRY
}

\author{
Natalia BULGARU ${ }^{a *}$, Irina-Olimpia SUSANU ${ }^{b}$ \\ ${ }^{a, b}$ Dunărea de Jos University of Galați, Romania
}

\begin{abstract}
The impact of the COVID-19 pandemic and quarantine conditions have significantly and still continues to adversely affect, tourism, which requires a careful analysis of the consequences of the crisis global impact on the hotel industry, in particular to identify the necessary solutions. Hotel units faced new problems: lack of guests, closure, declining revenues, staff and guest security. The hotel business will have to transform and further develop: to create apartment sectors of services under the leadership of international and local operators, to seek new forms of cooperation, to use new business technologies. To overcome the crisis, the hotel industry needs support from the state and viable solutions in the medium and long term.
\end{abstract}

KEYWORDS: hotel business, pandemic, development strategies, business transformation, state support

\section{INTRODUCTION}

Tourism is one of the largest industries in the global economy and has been both a key driver and a beneficiary of the prolonged period of economic growth seen in recent years (Robu \& Bălan, 2009). The outbreak of the COVID-19 virus was a blow to the tourism market, especially for the global hotel industry and implicitly for the Ukrainian one.

Closing down borders, cancellation of air services, traffic restrictions in Ukraine, between regions and the absolute isolation of countries between them caused - a lot of problems in the hotel sector and more. In a statistical context, tourism refers to the activity of visitors who travel to a destination outside their usual environment for less than a year (Cristureanu, 2012). Such trips may be made for any principal reason, including business, leisure or other personal reasons, other than employment by a resident employer, household or business in the place visited (Coshall \& Charlesworth, 2017). According to the UN World Tourism Organization (WTO) in 2020, the number of tourists will decreased by a third compared to 2019 and implicitly will lose about 50 million work places, related to the tourism industry. The hotel business in Ukraine is also in a difficult situation. Therefore, it is important to identify solutions to get out of the crisis with the lowest losses for hotel companies (Bereshchak, 2020).

\subsection{Analysis of Recent Research and Publications}

Specialists from the Association of Tourism Industry of Ukraine, Hotel Association and restaurants in Ukraine, The works of Nezdoyminov are dedicated to problems identified in the hotel industry (Nezdoyminov, 2016). The spread of COVID-19 and infectious diseases quarantine conditions have significantly affected and continue to adversely affect global tourism, so it is necessary to study the impact and effects of the crisis on the hotel industry, in particular to create the necessary conditions for overcoming the crisis (Kramarenko, 2020).

\footnotetext{
* Corresponding author. E-mail address: bulgaru.natalia@yahoo.com
} 


\title{
2. FORMULATION OF THE RESEARCH'S OBJECTIVES
}

\subsection{Analysis of the state of the tourism industry in Ukraine during the COVID-19 pandemic} Since the beginning of 2014, the market of tourist services in Ukraine (Bogomazova \& Yakovenko, 2018) has known a sharp decline, influenced by the unstable socio-economic situation, by aggression of the external army from the east, the annexation of the Crimean peninsula and a number of systemic problems such as: imperfect and unmodernized tourist infrastructure in big cities and in the country overall, insufficient quality of services, high prices, etc. The combination of these led to both a decrease in the number of foreigners coming to Ukraine and a decrease in domestic tourism, which negatively affected the development of tourism and gave a significant blow to the Ukrainian hotel industry (Kramarenko, 2020).

State borders closed, the abolition of air travel, travel restrictions both in states as well as in other countries, as well as continuous isolation have caused a number of problems in the hotel sector. Thus, according to the forecasts of the World Tourism Organization (WTO) of the United Nations, in 2020, the number of tourists will decrease by a third, compared to 2019.

Experts note that the catering industry (restaurants, bars, etc.) had a short time period to prepare for the future effects of coronavirus, while the hotel industry immediately faced this problem due to the specifics of management (Epuran et. al, 2017). Thus, after the introduction of quarantine, about 35$40 \%$ of hotels in Ukraine have closed, and others operate in a very limited way. Consequently, the main problem is the reduction or complete lack of profit. Hotels that continue to operate have lost $60-90 \%$ of their income. Also, the main consequences of the impact of the pandemic on tourism in Ukraine, in addition to the lack of guests, closure and decrease in revenue, experts include a cash gap, as the revenue has begun to suddenly drop to zero (Parfinenko, 2017).

To assess the impact of the Covid-19 epidemic on the accommodation sector from Ukraine, experts from Vertex Hotel Group and Colliers International (Ukraine) performed a questionnaire-based analysis of the Ukrainian hotel industry. The analysis was held from 20 to 21 March of 2020 and included 205 business hotel representatives in all regions of Ukraine.

The vast majority (96\%) (Fig. 1) of the respondents reported a sharp decrease of the application from 13 March 2020. Quarantine and termination of international services and domestic passenger traffic has led to a significant reduction in hotel occupancy. As a result, 85\% of respondents have already closed their institution, are preparing to close or are thinking about it. Among the surveyed representatives of 5 -star hotels - $42 \%$ said have no intends to close the institution under no circumstances.

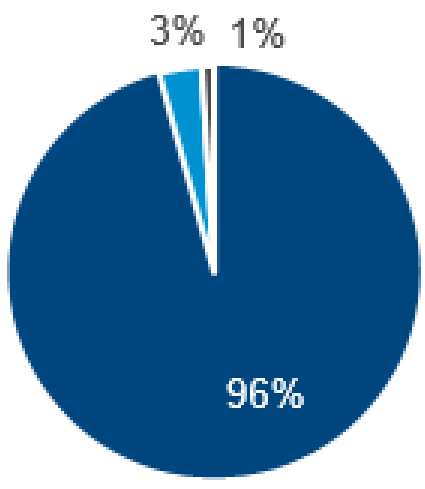

\author{
Demand has fallen sharply \\ (1) \\ The changes were not felt \\ - Demand has \\ improved \\ unexpectedly
}

Figure 1. The impact of coronavirus on the hotel business 2020

Source: Colliers International (2020) 
According to a survey conducted by Colliers International (Ukraine) and Vertex Hotel Group, the quarantine losses from March 13 to April 32020 are estimated at significant amounts:

- $40 \%$ of five-star hotels reported losses of 3 million UAH

- $10 \%$ - over 8 million UAH

- More than half (60\%) of the representatives of 4 and 3 star hotels estimate losses between 500,000 and 3 million UAH

- $70 \%$ representing hotels in other classes estimate losses of up to 500 thousand UAH.

Regarding the identification of possible strategies to get out of the crisis, the interviewed organizations are divided as follows:

- Over $77 \%$ of 5 -star hotel representatives say they are already building strategies to overcome the crisis after the epidemic, namely: entering new markets and introducing new services.

- Almost half (49\%) of the respondents representing 4 and 3 star hotels do not have other plans with exit strategies, while the other half chooses to introduce more innovative technologies and new services to overcome the crisis

- $41 \%$ of hotels with 2 stars or less do not have or are still working on their exit strategies from the crisis, the rest have decided that: they will introduce new services, innovative technologies and will enter new markets.

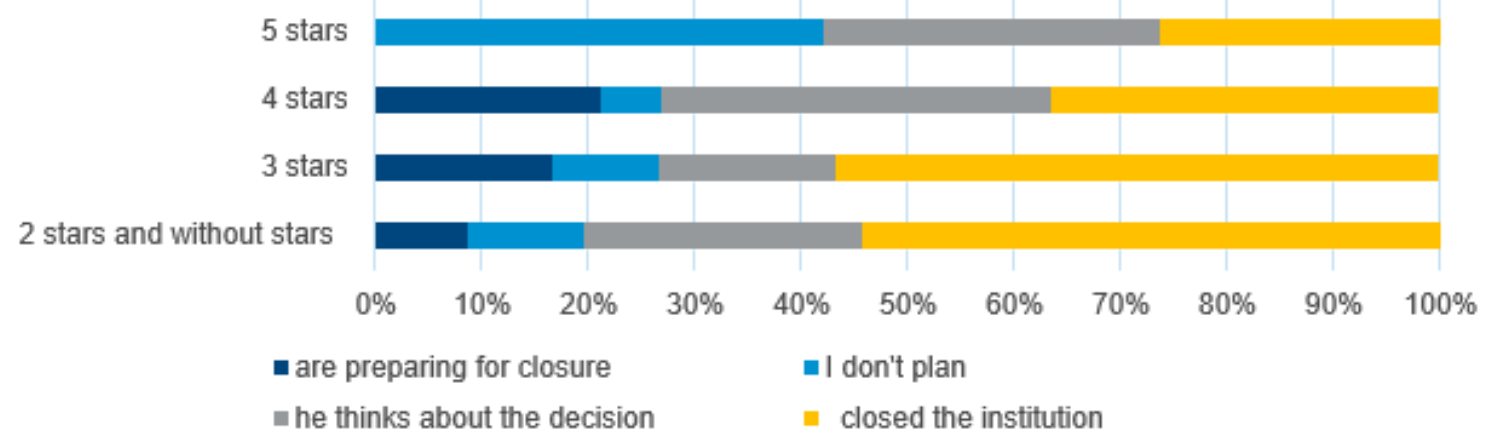

Figure 2. Attitude towards closing of the hotels

Source: Colliers International (2020)

\subsection{Identifying ways out of the hotel business crisis in Ukraine}

Strategic planning is seen as a necessity to sustain the business and its subsequent development in the face of the loss of a large number of potential customers under the influence of external and internal factors (Georgieva, 2020). The basis of a correctly chosen strategy is a correct evaluation of the relationship between price and quality of the proposed hotel product, which is expressed in practice by the ability to offer a quality hotel product at affordable prices for a specific target audience.

Such strategies include:

- differentiation strategy (providing a wide range of services different from other hotels);

- optimal cost strategy (creating the conditions for increasing consumer value through the superior quality of a hotel product at prices identical to those of competitors);

- focused strategy (represents the orientation of the hotel business towards a small segment of potential customers, offering either lower prices or customization of services);

- cooperation strategy (concluding agreements and partnerships for sustainable functioning of the hotel enterprise); 
- intellectual property strategy (brand creation, subsequent distribution through franchise). Thus, the application of the differentiation strategy imposes the need for additional marketing research related to the needs of potential guests, the study of consumer value of the hotel product, as well as the behavior of tourists. The differentiation will consist in adding new important services to existing basic and additional services for the target audience (Matis, 2020).

The bidding areas for the diversification of the hotel product, in our opinion, are: Improving the quality and safety of hotel services; simplification of the algorithm of booking, registration, as well as settlements with customers; ensuring compliance with the modern environmental norms, sanitary-epidemiological and other nature; offering a hotel product which increase the consumer's social status.

Concentrating on a small segment of the tourism market is possible with a focused strategy. The basis of segmentation can be both geographical location and business assignment hotels in a certain category or type. In this regard, the purpose of this strategy is to clearly meet the needs of a particular target group. To apply this strategy is needed a certain segment of customers who are willing to pay a higher price for additional properties of the tourist product. This strategy can be applied successfully in small hotels.

The influence of large hotel enterprises is minimized in a narrow segment, which is due to the lack of desire to compete with hotels with small opportunities. The globalization of socio-economic processes updates the use of the cooperation strategy. The emergence of alliances and partnerships in the hospitality industry is due to the creation of a favorable competitive position of hotel enterprises in the future, as well as consolidation of position today. The cooperation strategy is implemented in practice through training strategic alliances of hotel enterprises by concluding a cooperation agreement which goes beyond the contractual relationship between the two accommodation facilities - partners, but does not involves the merge of hotel enterprises. The purpose of the strategy is given by the fact that strategic alliances enables effective interaction over a long period of time, responding quickly to technological and competitive innovations, a current trend of the hospitality industry.

\subsection{Proposed measures to prevent stagnation in the hotel industry}

Thus, the possible strategies for overcoming the crisis are varied, each hotel company will choose the optimal solution, depending on the impact of external factors and its own indicators of operational activities (Andersen et al., 2020).

To support and mitigate the economic impact of the pandemic, the hotel industry is calling for the state to take the following measures:

- prohibition of unjustified fines, penalties and other financial penalties for the quarantine period and for 12 months there after;

- prohibition of accrual of interest and other payments for the use of credit funds;

- the obligation of banks and financial institutions to defer the payment of debts;

- reduction of VAT for hotel enterprises up to $10 \%$;

- abolition or reduction of land tax.

Among the important strategic decisions, which were constantly postponed by the government, we have already mentioned the VAT reduction for accommodation and food (hotels and restaurants), which is already provided for in the Association Agreement with the EU, but which has not yet been implemented. For example, Luxembourg has the lowest VAT in Europe, only 3\%. In the Ukraine, it is necessary to reduce VAT and thus attract investors. Also, we propose the abolition of the tourist tax, given that tourist flows will decrease sharply.

Thus, in order to increase the activity of the tourism industry, Ukraine needs:

- the creation of a strong investment microclimate;

- to provide tourists with comfortable and safe conditions to come to Ukraine; 
- to pursue an effective policy of mass tourism development, to develop and put in place an appropriate concept at the governmental level;

- the cancellation or simplification of the granting of visas for foreigners, especially for the most profitable countries;

- measures to improve the condition of monuments and create new tourist attractions;

- new opportunities for small business development in the hotel sector, which will increase the number of jobs and implicitly can become a source of foreign exchange earnings.

- transparency in its consumer activities;

- capital for business development;

- new investment projects, in particular in cooperation with government agencies

\section{CONCLUSIONS}

In conclusion, we would like to mention that in any pandemic scenario of COVID-19, the hotel industry will survive, but it will be transformed. If, hotel businesses, in the previous period, paid great attention to the occupancy of the rooms, the expansion the range of additional services and improving the quality of services, now the main task for these organizations is the safety of employees and guests. Therefore, at present they need to review and update:

- legal documents regarding the procedure for establishing the categories of hotels and other accommodation facilities;

- the rules for using enclosed spaces;

- regulations on design, construction, operation and planning in the hotel field.

More sophisticated technologies such as artificial intelligence, open software interfaces, augmented reality, use of voice assistants, blockchain, neurointerfaces, biometrics and facial recognition, require significant investments, which currently are not available to all hotel businesses.

To mitigate the economic impact of the COVID-19 pandemic, the hotel industry needs support from the state in the form of: holiday vouchers during pandemic, reduction of value added tax, reduction of land tax etc.

\section{REFERENCES}

Andersen, K. G., Rambaut, A., Lipkin, W. I., Holmes, E. C., \& Garry, R. F. (2020). The proximal origin of SARS-CoV-2. Naure Medicine, 26, 450-452. DOI: https://doi.org/10.1038/s41591020-0820-9

Bereshchak, V. (2020). Yak COVID-19 zminyt hotelnyi biznes v Ukraini. Retrieved April, 13, 2020, from https://thepage.ua/ua/exclusive/sho-stanetsya-z-gotelyami-cherez-koronavirus

Bogomazova, I. V. \& Yakovenko, O. V. (2018). International tourism market: state and development trends. Journal of History Culture and Art Research, 7(2), 699-707

Coshall, T. J. \& Charlesworth, R. (2017). A management orientated approach to combination forecasting of tourism demand, Tourism Management, 32, 759-765.

Cristureanu, C. (2012). International Tourism Economy and Policy, Bucharest: ABEONA Publishing House for Tourism and Culture

Epuran, Gh., Tescașiu, B., Todor, R. D., Sasu, K-A., \& Cristache, N. (2017). Responsible Consumption - Source of Competitive Advantages and Solution for Tourist Protection, Revista Amfiteatru Economic, 19, 45/2017

Galasyuk, S. S. \& Shikina, O. V. (2015). Organizational and economic principles of operation of small hotels: monograph. Odessa, CA: Atlant (in Ukrainian).

Georgieva, K. (2020). Join Statement by the Chair of International Monetary and Financial Committee and the Managing Director of the International Monetary Fund. International 
Monetary Fund, 20, 114-116. Retrieved March 27, 2020, https://www.imf.org/en/News/Articles/2020/03/27/pr20114-joint-statement-by-the-chair-ofimfc-and-the-managing-director-of-the-imf

Kramarenko, O. (2020). Holidays at the seaside 2020: resorts of Ukraine against Europe and coronavirus. Retrieved April 24, 2020, from http://krivbass.city/news/view/vidpochinok-namori-2020-kurorti-ukraini-proti-evropi-i-koronavirusu

Matis, C. (2020). A Study Regarding the Correlations that Exist between Types of Cultures in Banking Organizations and the Country of Origin of the Majority Capital, the Gender of the Employees, their Age, Level of Experience and Seniority the Organization, Annals of "Dunarea de Jos" University of Galati Fascicle I. Economics and Applied Informatics, 1, 4960 .

Nezdoyminov, S. G. (2016). Ukraine's hotel business in the context of market reforms. Ars Administrandi, 3, 97-106. (in Russian)

Parfinenko, A. Yu. (2017). Global transformations of the international tourism market and the hospitality industry. Bulletin of Karazin Kharkiv National University. Series: International Relations. Economy. Local lore. Tourism, 6, 175-186 [in Ukrainian].

Robu, V. \& Bălan, A. (2009). The analysis of competitiveness in the tourism sector in the actual context of economic crisis. Journal of tourism, 7, 84-89.

Association of small hotels and apartments of Ukraine. VGO "AMGAU". Retrieved January 6, 2020, https://vkursi.pro/card/vho-amhau-35142910.

Results of the Covid-19 impact survey to the temporary accommodation services sector. (n.d.). In Colliers International. Retrieved March 25, 2020 https://www2.colliers.com/ukua/research/2020-03-25-hotels-survey-colliers-international-2020. 